\title{
Jingpo Chinese
}

National Cancer Institute

\section{Source}

National Cancer Institute. lingpo Chinese. NCI Thesaurus. Code C158190.

A Chinese person from the Jing po ethnic group. 